\title{
Study of Green Logistics Managing Potential and the Preparedness of Auto Parts Industries in Thailand
}

\author{
Ampol Navavongsathian ${ }^{1}$, Dadanee Vuthipadadorn ${ }^{2}$, Sithichai Farangthong ${ }^{3}$, \\ Surat Janthongpan ${ }^{1}$, Roumpol Juntasart ${ }^{1}$ \\ ${ }^{1}$ Southeast Bangkok College, 298 Sunpawut Rd., Bangna, Bangkok,10260, Thailand \\ ${ }^{2}$ The Revenue Department, 90, Phaya Thai District, Bangkok, 10400, Thailand \\ ${ }^{3}$ Dhonburi Rajabhat University,172 Itsaraphap Rd, Thon Buri, Bangkok, 10600, Thailand
}

\begin{abstract}
This study aims to study green logistics managing potential and the preparedness of auto parts industries in Thailand. The statistical analysis is to identify factors with confirmatory factor analysis; oneway ANOVA is used to define relative factors affecting green logistics development of auto parts industries in Thailand. It can predict the results using multinomial logit modeling. The study suggests that factors affecting green logistics managing potential and the preparedness of auto parts industries in Thailand are environmental operations, internal green supply chain management, and external green supply chain management.
\end{abstract}

Keywords - green logistics, managing potential, preparedness, auto part industries.

\section{Introduction}

Green logistics is a way to create innovation in logistics and supply chain management, which is considered environmental. Consists of duties related to purchasing, reduction, recycling, reuse, and substitution of materials [1].

DOI: $10.18421 /$ TEM94-27

https://doi.org/10.18421/TEM94-27

Corresponding author: Ampol Navavongsathian, Southeast Bangkok College.

Email: n_ampol@yahoo.com

Received: 20 August 2020.

Revised: 27 October 2020.

Accepted: 02 November 2020.

Published: 27 November 2020.

(c) BY-NC-ND (c) 2020 Ampol Navavongsathian et al; published by UIKTEN. This work is licensed under the Creative Commons Attribution-NonCommercial-NoDerivs 4.0 License.

The article is published with Open Access at www.temjournal.com
The operational control and development of ecological operations require the integration of logistics and supply chain management systems such as the product design, selection of materials for production, production process, and product logistics to consumers. Including managing products that have reached the end of their life cycle or product life cycle [2]. Factors related to green logistics systems are to the management logistics system and supply chain management from upstream, midstream and downstream, which relates to green logistics, both directly and indirectly. Many industries need to operate with business partners, especially suppliers and components, to collaborate in creating green products from upstream, which is necessary for survival and competitiveness both nationally and internationally.

Green logistics and supply chain management strategies will eventually become a critical success factor for the industry. Green logistics contains green purchasing, green manufacturing, green material management, green distribution, marketing, and reverse logistics management [3].

The auto parts industries are a group of targeted industries that the Thai government supports because they are industries that play a role in supporting the automotive industry. Thailand is one of the crucial large production bases in the world. Furthermore, it is essential for the country's economic system both in the area that produces a large number of employees and causing connections with various related industries. However, the auto parts industries in Thailand need to focus on enhancing the capability of the design. Development is also improving the quality of production and reducing production losses by raising the level of production technology and creating a competitive advantage in green logistics and supply chain management while reducing logistics costs to enable the auto parts industries in Thailand to survive and compete in the global competitive arena. The researchers have, therefore, studied green logistics managing potential. The preparedness of auto parts 
industries in Thailand to be a guideline for creating innovation in the logistics management process and system development green logistics. It can be applied to enhance the efficiency and effectiveness of auto parts industries in Thailand and determine public policy direction for competitive advantages in the global market.

\section{Thai Automotive and Auto Parts Industries}

In the global economy, the automotive and auto parts industry has quickly become an industry. Leading automotive industry leaders such as Honda, Toyota, General Motors, Ford, Daimler Chrysler, Suzuki, Hyundai, and Fiat are nationals in Asia [4]. They mention spread regions world due to energy issues, and the environmental policy of every government in many countries around the world. It became an international policy that the automotive and auto parts industries must put into their systems and management strategies to comply with the government regulations in that country. To the automotive industry and auto parts it is vital to reduce the impact on the environment scramble and create a competitive advantage in the market and ensuring compliance with environmental regulations [5]. Also, Zhu et al. [6] see that the automotive and auto parts industry in developing countries have high potential and have an obligation to be able to manage to be green due to intense competition in the market, especially after entering the World Trade Organization (WTO). For Thailand, the automotive industries and auto parts are considered very important to the Thai economy's development. Thailand is the most extensive production base for automobiles in the ASEAN region. The automotive industries and auto parts are related to enterprises in more than 160 branches, such as steel, plastic, rubber, and electronics. And most small auto parts manufacturers (tier 2 and tier 3) still have the production process that is not up to date and using high energy for production and also cause pollution to the environment. Therefore, the concept of green logistics and supply chain management in the automotive industry and auto parts in Thailand will focus on evaluation and increasing the efficiency of these processes to reduce environmental impact and reduce energy use.

\section{Green Logistics and Green Supply Chain Management}

Development concepts and theories related to green focus on the sustainability of businesses and the environment, driven by regulatory factors - the Kyoto Protocol of 1997, followed by the Copenhagen Protocol and Trade Barriers [7].
The literature on green logistics and green supply chain, in many cases, address issues of production cost drivers [8], quality [9], risks [10], and sustainable management for implementation [11].

If research and literary group study about green logistics and supply chains is established, green can be grouped into four groups altogether: the first group, which is the operational perspective, describes the operational process, operation activities, decision efficiency and effectiveness of operations. The second group is a valuable perspective in customers' eyes, which involves customers and industry needs, quality, value, and customer expectations. The third group of costs is the logistics perspective. Which involves literature about transportation, warehouse networks, supply chain strategies, and the last group is green perspective, which refers to green or the green supply chain operations and corporate responsibility towards the community [12]. To visualize the integration of the green logistics and supply chain management perspective in the overall picture, Figure 1. shows the model of the green logistics management system, and green supply chain which has a goal at the center managed to achieve sustainability or the green view or to be green which is explained by the four aspects, which are: the customer perspective, the event and flexibility perspective, the logistics perspective and the green perspective (see Figure 1.).

\section{The Customer Perspective}

Consists of objectives for the value of the customer (cost and product quality), risk management throughout the organization to avoid situations that threaten the organization and efficient production process.

\section{Event and Flexibility}

Consisting of the purpose of speed in transportation, scheduled delivery, acceptance of members throughout the supply chain from upstream, midstream, and downstream, implementation of activities throughout the supply chain, efficiency, and effectiveness correspond to the internal and external environment of the organization.

\section{Logistics Perspective}

Consists of the objectives of the essential functions of logistics to ensure the correct product at the right time and the right place.

\section{Green Perspective}

Consists of the input reduction objective, safety objective and pollution efficiency objective (e.g. $\left.\mathrm{CO}_{2}\right)$ 


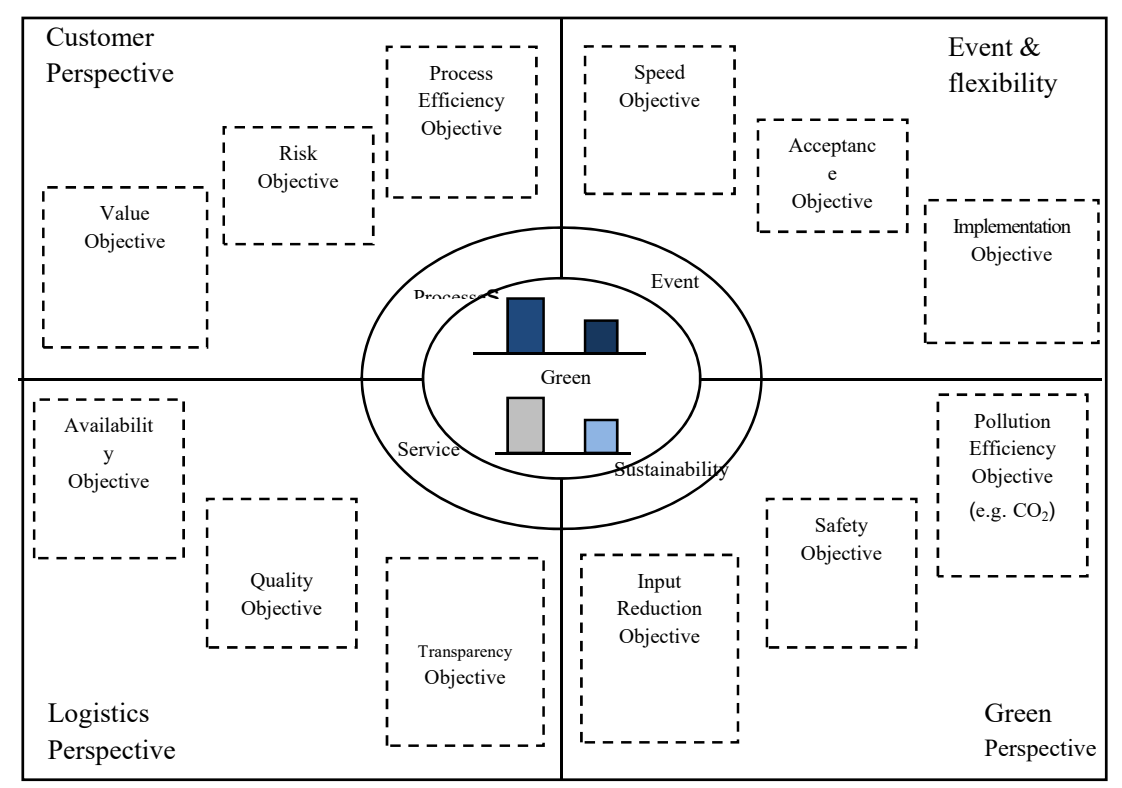

Figure 1. Green logistics system and supply chain management model Source: Klumppet al., 2010

\section{Literature Review}

The literature in green logistics and green supply chain management arose as organizations, and researchers begin to realize that management and environment programs and operations do not end to the boundaries of the organization [13]. Jain and Sharma [14] conducted a green supply chain management practice in the automobile industry: an empirical study to combine modern management strategies in the automotive and automotive parts industry. The study results found that the GSCM methodology to be successful must start from the initial management process. Moreover, they found that the automotive industries and auto parts industries in India have the potential to develop management to be environmentally friendly. Furthermore, Sharma and Jain [14] researched the impact of green supply chain management practices on organizational performance. The research results show that green design, green manufacturing, reverse logistics, environmental operations, economic operations are closely related to green corporation performance.

While Zhu, Sarkis, and Lai [16] study the factors driving the green supply chain management in China's automotive industry. By considering only the economic and environmental factors such as the cost of purchasing raw materials, energy cost, waste treatment costs, the amount of wastewater, solid waste, and air emissions. The study found that green supply chain management is an issue of green purchasing management, green marketing, and ecodesign. Besides, Lin, Chen and Nguyen [17] studied green supply chain management performance in the automobile manufacturing industry under uncertainty, to find the factors that affect GSCM operations in the automotive and auto parts industries in developing countries. The study found that the key factors that lead to environmental management of the automotive sectors and auto parts industries in developing countries are the commitment to action to achieve the industry's green operation and strict control of industrial and environmental pollution.

Stephan and Robert [18] have presented GSCM research, focusing on the integration of upstream and downstream supply chain management. The study will consider (1) joint environmental activities between manufacturers and suppliers as well as manufacturers and customers, (2) biological surveillance activities with suppliers and customers, (3) systems cooperation activities logistics with suppliers and customers. Investigation of pressures and drivers for adoption and improving environmental performance arises from several external and internal groups or stakeholders. The literature has identified some potential groups that will influence the organizational adoption of GSCM and other ecological practices. The main categories of internal and external drivers of green supply chain management practices include organization factors, regulation, customers, competitors, and society and supplies. Some aspects of green supply chain management, including sustainability, sustainable and green supply chain management and GSCM drivers, practices, and performance among manufacturing organizations, and identified through the existing body of literature are internal environment management, external GSCM, investment recovery, and eco-design. Previous research has explored the relationship between GSCM practices and performance, including environmental, economic, and operational performance. 
Firouazbadi and et al. [19] developed the main GSCM performance items:

1. environmental performance: reduction of air emission, reduction of wastewater, reduction of solid wastes, decrease of consumption for hazards/harmful/toxic materials, a decrease of frequency for environmental accidents, improve an enterprise's ecological situation,

2. positive economic performance: reduction of cost of materials purchasing, a drop of value for the end, and decrease of fine for environmental accidents,

3. negative financial performance: increase of investment, improvement of operational cost, growth of the expenses for purchasing environmentally friendly materials and expansion of training cost, and

4. operational performance: increase amount of goods delivered on time, decrease inventory levels, decrease scrap rate, promote products' quality, expanded product line, and improved capacity utilization.

\section{The Organizational Theory}

Describes the focus within corporate management to explain organizational behavior, design, and management structure. Especially coordination between departments in the organization, and when considering the control of the supply chain, it will make the importance of working relationships within the organization more clearly. Organization theory can be applied to describe operations within the organization and manage internal and external environments [20]. When used to describe logistics management and supply chain, it makes it possible to understand the potential and possibilities, including sustainable growth determination of vision directions for the future in green logistics and green supply chains that need to integrate organizational theory, coordination, success throughout the supply chain, and creating value in the green supply chain.

\section{Green Supply Chain Theorem (A brief history of GSCM)}

Supply chain management was first published in the 20th century [21], such as lean management and timely production (just-in-time-JIT) with the primary objective of producing efficient and minimizing waste. Evidence of a significant publication by Rachel Carson in the analysis of "silent spring", which was the result of severe pollution problems. Later, economists and environmentalists took the environment in academia seriously. Pollution has played a role in the industry since then. The environment has been discussed in academics by economists and environmentalists, beginning the industry's role in the background since then [22] and followed by the academic results of the following issues. In other words, such as supply chains and sustainable demand or the corporate social responsibility network managing the green supply chain procurement [23], environmental procurement management, green Logistics and supply chain and sustainable supply chains, etc.

\section{Ecological Modernization Theory (EMT)}

Modern management theory for environmental conservation is a sociological theory and has developed from policy and organization theory to the theory of innovation for the environment. This theory describes the coordination of industrial development and environmental protection through the evolution of innovation and technology [24]. However, the creation of ecological changes may not bring monetary benefits for all organizations but brings a good corporate image and product. The business of EMT's concept of integration with green supply chains in both win-win situations arises, which is an essential incentive for large companies in the supply chain to building green systems for suppliers, inputs, and customers in the supply chain ends [25].

\section{Resource - Based View Theory}

Fundamental theory of the resource used to describe the competitive advantage of an industry leads to sustainability by using resources to maximize value. Because resources may be scarce, irreplaceable, this theory describes the use of all resources, competencies and organizational management processes. Business unit information and knowledge control the organization's work to implement strategies to achieve the goal of improving efficiency and effectiveness and finally making a competitive advantage [15]. The resource base is vital in the supply chain through customer management systems within the organization, which involves learning to use the organization's resources. In the supply chain, knowledge sharing for resourcesharing in an environmentally friendly learning direction leads to a green supply chain, which must answer the relationship between the uses of resources within an organization and how external pressures can continue to work together in a way that creates organizational competitiveness.

Therefore, from the literature review, both concepts theories and related researches are intensified under the scope of this research. Table 1. shows the factors affecting green logistics managing potential and the preparedness of auto parts industries in Thailand and leads to the creation of a conceptual framework in Figure 2. 
Table 1. The factors affecting green logistics managing potential and the preparedness of auto parts industries in Thailand

\begin{tabular}{|c|c|}
\hline Practices/Performances & Parameters \\
\hline \multirow{5}{*}{ Environmental Operations } & Attention to pollution control \\
\hline & Use of environmentally friendly technology \\
\hline & Partnerships with green organizations and suppliers of inputs \\
\hline & There is a training program for green personnel \\
\hline & $\begin{array}{l}\text { There are rules and obligations for the green management within the } \\
\text { organization itself }\end{array}$ \\
\hline \multirow[t]{2}{*}{ Operation Positive Economic } & $\begin{array}{l}\text { Reducing raw material procurement costs } \\
\text { Reducing energy costs }\end{array}$ \\
\hline & Reducing waste disposal fees \\
\hline \multirow[t]{2}{*}{ Operation Negative Economic } & $\begin{array}{l}\text { Increase investment } \\
\text { Increasing operating costs }\end{array}$ \\
\hline & Increasing costs for the purchase of environmentally friendly raw materials \\
\hline \multirow[t]{4}{*}{ Operational Green } & Scrap / scrap reduction \\
\hline & Quality improvement \\
\hline & Delivery improvements \\
\hline & Improvement of best practice management system \\
\hline \multirow{6}{*}{$\begin{array}{l}\text { Internal Green Supply Chain } \\
\text { Management }\end{array}$} & Senior managers have an obligation to implement green supply chains \\
\hline & Middle managers support the implementation of green supply chains \\
\hline & There is coordination across departments for environmental improvement \\
\hline & There is environmental quality management throughout the organization \\
\hline & Actions taken to obtain the ISO14001 certificate \\
\hline & The program is used to monitor and track environmental issues \\
\hline \multirow[t]{4}{*}{$\begin{array}{l}\text { External Green Supply Chain } \\
\text { Management }\end{array}$} & $\begin{array}{l}\text { The raw material properties and procurement systems are in accordance with } \\
\text { environmental guidelines }\end{array}$ \\
\hline & $\begin{array}{l}\text { There is coordination with the suppliers of production factors for } \\
\text { environmentally friendly purposes }\end{array}$ \\
\hline & $\begin{array}{l}\text { There are environmental issues examined for management within the company } \\
\text { of suppliers of production factors }\end{array}$ \\
\hline & $\begin{array}{l}\text { Manufacturers of inputs have received ISO14000 } \\
2^{\text {nd }} \text {-tier suppliers have green practices }\end{array}$ \\
\hline \multirow[t]{2}{*}{$\begin{array}{l}\text { Collaboration Customers } \\
\text { /Suppliers for Green Logistics }\end{array}$} & $\begin{array}{l}\text { Cooperation with customers for eco-friendly designs cooperation with } \\
\text { customers for clean production processes collaboration with customers for } \\
\text { green packaging }\end{array}$ \\
\hline & Cooperation with customers to reduce energy consumption during shipping \\
\hline \multirow{2}{*}{$\begin{array}{l}\text { Investment for Redemption for } \\
\text { Green Logistic }\end{array}$} & $\begin{array}{l}\text { Adjusting environmental investments by selling raw materials and excess } \\
\text { inventory }\end{array}$ \\
\hline & Sales of surplus capital equipment \\
\hline \multirow[t]{3}{*}{ Green Products Design } & Recycle/Renovated both materials and components \\
\hline & Designing products for recycling. \\
\hline & Product design to avoid or reduce the use of dangerous products and processes \\
\hline \multirow[t]{2}{*}{ Product Life Cycle Assessment } & $\begin{array}{l}\text { Evaluation Investment in recycling } \\
\text { Retrospective logistics operations }\end{array}$ \\
\hline & Product life cycle management \\
\hline $\begin{array}{l}\text { Budget for Green Supply } \\
\text { Chain Management }\end{array}$ & $\begin{array}{l}\text { Green has set out an operational strategy plan } \\
\text { Have research and development for environmental } \\
\text { ISO14001 quality management system }\end{array}$ \\
\hline \multirow[t]{3}{*}{ Total Green Activities } & $\begin{array}{l}\text { The level of information systems related to green } \\
\text { Green transport } \\
\text { Green purchasing }\end{array}$ \\
\hline & Green logistics \\
\hline & Green production \\
\hline
\end{tabular}




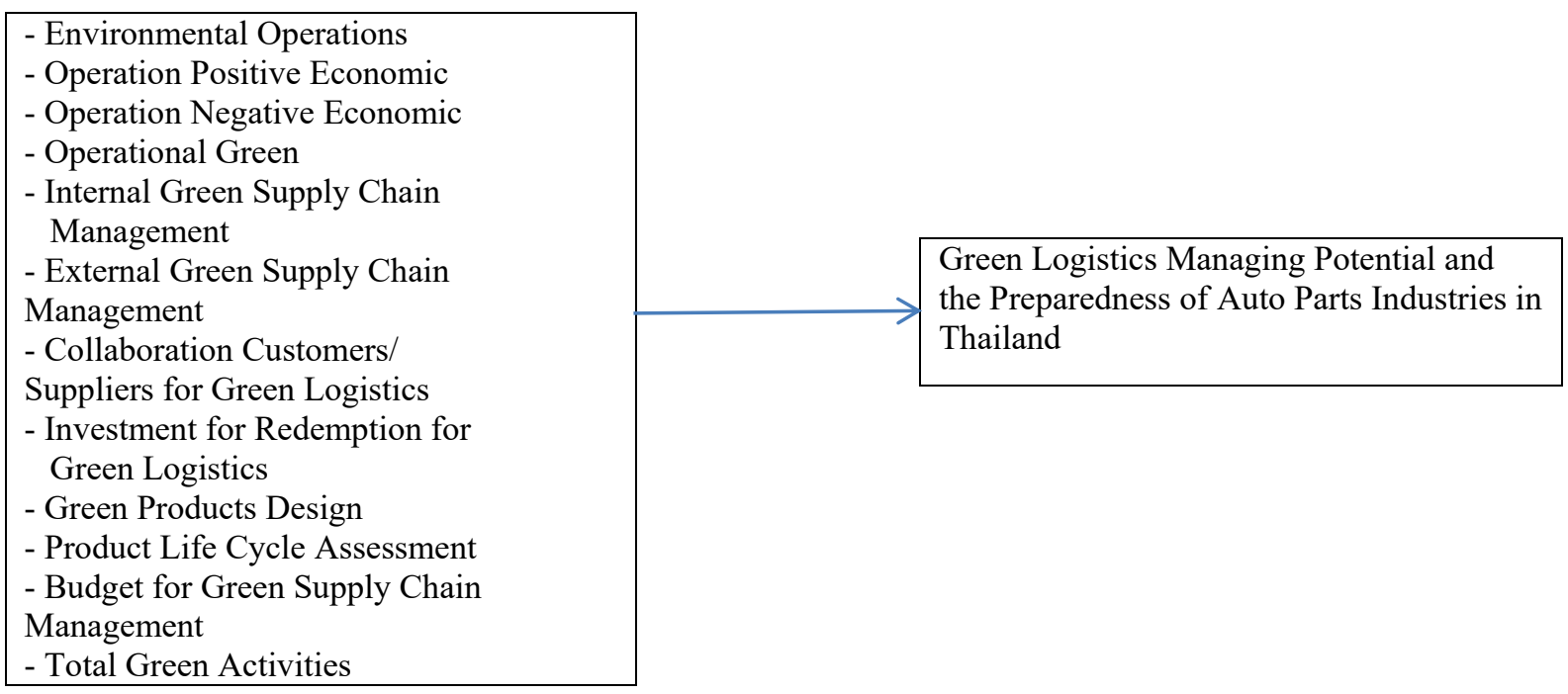

Figure 2. Conceptual framework of green logistics managing potential and the preparedness of auto parts industries in Thailand

\section{Research Methodology}

The starting points were the studying of green logistics managing potential and the preparedness of auto parts industries in Thailand. The unit of analysis was the auto parts industry in Thailand. The questionnaire-based survey was applied to sample 368 auto parts industries in Thailand from tier-1, tier2 , and tier-3 auto parts manufacturers by using a multinomial logit model for selecting factors affecting green logistics managing potential, and the preparedness of auto parts industries in Thailand. This study used a quantitative research methodology by using questionnaires which were successfully tested for the validity and reliability of questionnaires. The qualitative research methodology was used in this study with an in-depth interview to test the quantitative method results, and the qualitative method results by the triangulation approach. The statistical analysis of this study was to identify factors with confirmatory factor analysis; a one-way ANOVA. It used to define different factors and relative factors affecting green logistics development of auto parts industries in Thailand. That could predict the results using a multinomial logit model to predict the choice behavior of green logistics management of auto parts industries in Thailand.

\section{Research Results and Discussions}

Confirmatory factor analysis under the 12 groups of variable assumptions, including Environmental Operations (OE), Operations Positive Economic (OPE), Operations Negative Economic (ONE), Operations Green (OG), Internal Green Supply Chain Management (IGSCM), External Green Supply Chain Management
(EGSCM), Collaboration Customer/ Suppliers for Green Logistics (CSFG), Investment for Redemption for Green Logistics (IG), Green Product Design (DG), Product Life Cycle Assessment (PLCA), Budget for Green Supply Chain Management (BFG) and Total Green Activities (TTG)to verify the model. Correlate whether it is appropriate or not to measure the relationship between all variables. The analysis results show that the model for measuring all 12 groups of factors is appropriate and acceptable. The list of all questions can measure the relationship of variables appropriately in what needs to be measured based on the hypothesis. When analyzed from the factor loading, the Environmental Operations (OE)is high value (between 0.824-0.872),Operations Positive Economic (OPE) is high value (between 0.6320.736), Operations Negative Economic (ONE)is high value (between 0.688-0.815), Operations Green (OG)is high value (between 0.701-0.765), Internal Green Supply Chain Management (IGSCM)is high value (between 0.678-0.852, External Green Supply Chain Management (EGSCM) is high value (between 0.689-0.821), Collaboration Customer/Suppliers for Green Logistics (CFG) is high value(between 0.645-0.852), Investment for Redemption for Green Logistics (IG) is high value (between 0.881-0.842), Green Product Design (DG) is high value (between 0.619-0.634), Product Life Cycle Assessment (PLCA)is high value (between 0.784-0.824), Budget for Green Supply Chain Management (BFG) is high value (between 0.801 to 0.892 ) and Total Green Activities (TTG) is high value (between 0.796 to 0.901 ). By statistical tests chi-square goodness-of-fit, there are statistically significant differences, which show that all the structural groups are structurally related. And have confidence that the model used in the forecasting of independent variables and structural variables based on assumptions and that the data entered in the model is valid and reliable.To answer the objectives of this research, it is to study of green logistics managing 
potential and the preparedness of auto parts industries in Thailand, so the samples were classified by the first-tier components, which are manufacturers of equipment directly into the automobile and motorcycle assembly plant. The second- tier is the manufacturer of sub-parts or procuring raw materials to supply the first-tier. The thirdtier is the manufacturer of sub-parts or purchasing raw materials to provide the first-tier and the second- tier.
The one-way analysis of variance (ANOVA) uses to determine the different variables and correlate them with the factors. That affects green logistics managing potential and the preparedness of auto parts industries in Thailand, which means the level studying industrial groups, the first- tier, the second-tier, and the third-tier. The analysis results by F-test are shown in Table 2.

Table 2. Compares the mean of green logistics managing potential, and the preparedness of auto parts industries green in Thailand in the first tier, the second-tier, and the third tier

\begin{tabular}{|c|c|c|c|c|c|c|c|c|}
\hline \multirow[b]{2}{*}{ list } & \multicolumn{2}{|c|}{ Tier $1(n=78)$} & \multicolumn{2}{|c|}{ Tier $2(n=88)$} & \multicolumn{2}{|c|}{ Tier $3(n=220)$} & \multirow[t]{2}{*}{$\mathrm{F}$} & \multirow[t]{2}{*}{ Sig. } \\
\hline & Mean & $\begin{array}{l}\text { Standard } \\
\text { Deviation }\end{array}$ & Mean & $\begin{array}{c}\text { Standard } \\
\text { Deviation }\end{array}$ & Mean & $\begin{array}{c}\text { Standard } \\
\text { Deviation }\end{array}$ & & \\
\hline $\begin{array}{l}\text { Environmental } \\
\text { Operations (OE) }\end{array}$ & 3.99 & 0.89 & 2.82 & 0.82 & 2.41 & 0.78 & 7.23 & $0.000 *$ \\
\hline $\begin{array}{l}\text { Operations Positive } \\
\text { Economic (OPE) }\end{array}$ & 3.33 & 0.78 & 2.41 & 0.74 & 2.11 & 0.86 & 1.52 & 0.253 \\
\hline $\begin{array}{l}\text { Operations } \\
\text { Negative Economic } \\
(\text { ONE) }\end{array}$ & 3.70 & 0.81 & 2.41 & 0.69 & 2.13 & 0.73 & .042 & 0.952 \\
\hline $\begin{array}{l}\text { Operations Green } \\
\text { (OG) }\end{array}$ & 3.60 & 0.72 & 2.68 & 0.77 & 1.68 & 0.62 & 1.33 & 0.631 \\
\hline $\begin{array}{l}\text { Internal Green } \\
\text { Supply Chain } \\
\text { Management } \\
\text { (IGSCM) }\end{array}$ & 3.69 & 0.82 & 3.35 & 0.84 & 2.54 & 0.80 & 4.89 & $0.000 *$ \\
\hline $\begin{array}{l}\text { External Green } \\
\text { Supply Chain } \\
\text { Management } \\
\text { (EGSCM) }\end{array}$ & 3.57 & 0.69 & 2.77 & 0.71 & 2.40 & 0.78 & 6.64 & $0.003 *$ \\
\hline $\begin{array}{l}\text { Collaboration } \\
\text { Customer/Suppliers } \\
\text { for Green Logistics } \\
(\mathrm{CFG})\end{array}$ & 3.25 & 0.88 & 2.68 & 0.84 & 2.25 & 0.74 & 0.56 & 0.652 \\
\hline $\begin{array}{l}\text { Investment for } \\
\text { Redemption for } \\
\text { Green Logistics } \\
\text { (IG) }\end{array}$ & 3.49 & 0.78 & 2.56 & 0.73 & 2.23 & 0.69 & 0.53 & 0.931 \\
\hline $\begin{array}{l}\text { Green Product } \\
\text { Design (DG) }\end{array}$ & 3.31 & 0.82 & 2.42 & 0.72 & 2.14 & 0.78 & 0.55 & 0.726 \\
\hline $\begin{array}{l}\text { Product Life Cycle } \\
\text { Assessment (PLCA) }\end{array}$ & 3.11 & 0.72 & 2.45 & 0.91 & 2.11 & 0.85 & 2.11 & 0.668 \\
\hline $\begin{array}{l}\text { Budget for Green } \\
\text { Supply Chain } \\
\text { Management (BFG) }\end{array}$ & 3.31 & 0.82 & 2.38 & 0.78 & 2.12 & 0.76 & 0.84 & 0.934 \\
\hline $\begin{array}{l}\text { Total Green } \\
\text { Activities (TTG) }\end{array}$ & 3.22 & 0.92 & 2.23 & 1.05 & 1.89 & 1.12 & 0.63 & 0.248 \\
\hline
\end{tabular}

Note: The operational level is 1 = not yet implemented; 2 = planning to proceed;

3 = considering ongoing; 4 = partially implemented; 5 = fully operational

Table 2. shows the groups of variables in Environmental Operations (OE), Internal Green Supply Chain Management (IGSCM), and External Green Supply Chain Management (EGSCM). There is a significant difference (at the level of 0.05 ) from a total of 12 variable groups, which are factors green logistics managing potential and the preparedness of auto parts industries in Thailand. In this research, the mean score determined that if the auto parts industries in Thailand have an average score of 3.00-3.99, it recommended that the auto parts industries have environmental management and logistics management which are implemented with an average score of 4.00 or higher, indicating that the auto parts industries have environmentally-friendly logistics management, which has been put into operation seriously and has 
continuously expanded the process of environmentally friendly logistics management.

\section{Environmental Operations}

Study results show that Environmental Operations are the essential activity of green logistics managing potential. And the preparedness of auto parts industries green in Thailand consists of attention to pollution control, the use of environmentally friendly technology, partnerships with green organizations, and suppliers of production factors. The organization recognizes the importance of obtaining an environmental quality certification, having a green personnel training program, regulation, and a commitment to implementing green management within the organization. These activities are an essential ecological activity for the auto parts industries in Thailand.

Table 2. shows that the respondent's group, which are the auto parts industries in Thailand, the research results were found that the first-tier group has Environmental Operations, with the highest average score of 3.99. Followed by the second-tier group with an average score of 2.82. And the lowest in the third tier has an average score of 2.41 , which shows that the first-tier is a large industrial group. There have been serious environmental actions, and the scope of green logistics management has increased. While the second-tier manufacturers were currently in the planning process. Furthermore, considering environmental effects showed a tendency towards a lack of focus on Environmental Operations. It also includes third-tier manufacturers and second-tier manufacturers that have not yet taken environmental action into action.

\section{Internal Green Supply Chain Management}

Green supply chain management within an organization is an essential activity for environmental logistics management in the auto parts industries in Thailand. Consisting of control in which senior managers must implement green supply chains, midlevel managers supporting the implementation of green supply chains, cross-agency coordination to improve things environmentally, environmental quality management throughout the organization, a program to monitor environmental issues and the application to obtain the ISO14001 certificate.

From Table 2. It is shown that the respondent's group, which is the auto parts industries in Thailand, in the first-tier group, has a green supply chain management within the organization. The highest average score was 3.69 , followed by the second-tier group with an average score of 3.35. The lowest, which was the third-tier, has an average score of 2.54, which shows that the first-tier group and second-tier group have implemented green supply chain management within the organization. Meanwhile, the second-tier group considered, showed a lack of emphasis on green supply chain management within the organization, which means there is no implementation of green supply chain management in the organization.

\section{External Green Supply Chain Management}

Green supply chain management from outside the organization is an essential activity for environmental logistics management of the auto parts industries in Thailand. Consisting of the raw material properties and procurement systems that comply with the green criteria, internal control of suppliers are examined for environmental issues and received ISO14000 certificate and 2nd-tier suppliers with eco-friendly practices.

Table 2. shows the respondent's group, which is the auto parts industries in Thailand. In the first- tier group it has a model of green supply chain management from outside the organization. The highest average score of 3.57 , followed by the second-tier group with an average score of 2.77 . Consisting of the third-tier group which has an average score of 2.40 , indicating that the first- tier has already implemented some green supply chains within the organization while the second- tier group is in the process of being considered. It shows a tendency towards a lack of external supply chain management from the organization, which means there is no implementation of green supply chain management from outside the organization.

\section{Multinomial Logit Model}

In the analysis based on the conceptual framework, this research was using a multinomial logit model for predicting choice behavior of green logistics management of auto parts industries in Thailand. Determine the relationship of the response variable and variable explained (Independent variable) in the logistical model in the case that the model is baselinecategory logit model when the variable responds in sequence;

$$
\log \left(\frac{\pi_{j}}{\pi_{J}}\right)=\alpha_{j}+\beta_{j}^{\prime} x, j=1, \ldots, J-i
$$

Where the values of $\propto j$ and $\beta \mathrm{j}$ represent the vector parameters in the model when $j=1,2, \ldots J-$ $i$ represents the group of response variables with $J=3$ groups. 
Table 3. The number and percentage of auto parts industries that has environmentally friendly logistics management classified by parts manufacturer, level 1 (tier 1), level 2 (tier 2) and level 3 (tier 3)

\begin{tabular}{cccc}
\hline Auto parts industries & Value of variable & Total frequency & Percent \\
\hline tier 1 & 1 & 78 & 20.21 \\
tier 2 & 2 & 92 & 23.80 \\
tier 3 & 3 & 216 & 56.00 \\
\hline Total & & 386 & 100.00
\end{tabular}

Table 3. shows 386 samples of auto parts industries that have environmentally friendly logistics management. There is tier 3 group of 216 auto parts manufacturers, which accounted for $56.00 \%$, followed by the tier 2 in the amount of 92 companies, representing $23.80 \%$, and the smallest group of tier 1 in the amount of 78 companies, representing $20.21 \%$

Table 4. Wald and P-value statistics for the impact of explanatory variables affecting response

\begin{tabular}{lccc}
\hline \multicolumn{1}{c}{ Effect } & DF & Wald & P - value \\
\hline Environmental Operations (OE) & 2 & 26.3645 & 0.0003 \\
Internal Green Supply Chain Management (IGSCM) & 2 & 31.2846 & 0.0001 \\
External Green Supply Chain Management (EGSCM) & 2 & 37.9642 & 0.0005 \\
\hline
\end{tabular}

Table 4. shows the described variables that are selected into the logit model with stepwise likelihood ratio selection using stepwise methods, such as
Environmental, Operational(OE)variables, Internal Green Supply Chain Management (IGSCM), and External Green Supply Chain Management (EGSCM).

Table 5. Estimation coefficients of the logit model in the case that the variable responds without sequence

\begin{tabular}{cccrrrr}
\hline Parameter & Goals & DF & \multicolumn{1}{c}{$\boldsymbol{\beta}$} & S.E. $(\boldsymbol{\beta})$ & $\begin{array}{c}\text { Wald } \\
\text { Statistics }\end{array}$ & P - value \\
\hline Intercept & 1 & 1 & 0.1016 & 0.2321 & 12.1643 & $<.0001$ \\
Intercept & 2 & 1 & -0.1669 & 0.1220 & 13.2451 & 0.0001 \\
OE & 1 & 1 & -0.2576 & 0.1328 & 5.06169 & 0.0001 \\
OE & 2 & 1 & 0.1656 & 0.1343 & 3.4545 & 0.0000 \\
IGSCM & 1 & 1 & -0.1249 & 0.1606 & 17.1245 & 0.0127 \\
IGSCM & 2 & 1 & 0.1881 & 0.1569 & 18.1529 & 0.0634 \\
EGSCM & 1 & 1 & -0.2624 & 0.1306 & 25.8546 & 0.0000 \\
EGSCM & 2 & 1 & 0.3647 & 0.1567 & 28.6342 & 0.0002 \\
\hline
\end{tabular}

From Table 5. the coefficient estimation of the logit method model obtained from the maximum likelihood can be written as follows:

$$
\begin{aligned}
\log \left(\hat{\pi}_{1} / \hat{\pi}_{3}\right) & =0.1016-0.2576 \text { EP }-0.1249 \text { IEM }-0.2624 \text { EGSCM } \\
\log \left(\hat{\pi}_{2} / \hat{\pi}_{3}\right) & =-0.1669+0.1656 \text { EP }+0.1881 \text { IEM }+0.3647 \text { EGSCM } \\
\log \left(\hat{\pi}_{1} / \hat{\pi}_{2}\right) & =2.1543+0.1574 E P-0.3264 \text { IEM }+0.3598 \text { EGSCM }
\end{aligned}
$$

The results of the above logit model show thevariable of Environmental Operations (OE), Internal Green Supply Chain Management (IGSCM) and External Green Supply Chain Management (EGSCM) with statistical significance of 0.05 .

All models can be described as the increase in Environmental Operations (OE), resulting in managers in the auto parts industries in Thailand, both tier-1, tier-2, and tier-3, will require environmental action. However, the Environmental Operations (OE) variable affect the auto parts manufacturer tier-2 and tier-3 the most, with an increase in Internal Green Supply Chain Management (IGSCM) and External Supply Chain Management (EGSCM). As a result, managers in the auto parts industry in Thailand, both tier-2 and tier-3, will have to take action on Internal Green Supply Chain Management (IGSCM) and External Supply Chain Management (EGSCM). 


\section{Conclusions and Suggestion}

The research shows that, in general, more than half of the auto parts industries in Thailand still lack knowledge, experience, and tools to create and improve efficiency and effectiveness in enhancing environmental operations by accepting best practices and practices in the environmental industry, especially with suppliers and customers, as well as an increase in regulatory pressure and strict supervision from relevant government agencies' bargaining power of auto parts operators and customers in the supply chain. The research clearly shows that the auto parts industries in Thailand, especially in the nearly third-tier component manufacturers, lack the acceptance of severe environmental logistics management. More than half of the second-tier manufacturers are already planning and have implemented some parts. The lack of adoption of green logistics management especially in the assessment of product life cycle, such as investment in conversion backtracking logistics operations and product life cycle management, etc. in terms of green activities throughout the organization, such as the level of information systems on green transport, green purchasing, green logistics, and green production, etc., which may affect the competitiveness of the operators themselves and affecting the entire supply chain including the ability and the competitive advantage of the Thai auto parts industries in the world stage of the competition. Suggestions from this research include;

1. The auto parts industries in Thailand should accept and manage environmental logistics in the following groups: Environmental Operations, Internal Green Supply Chain Management and External Green Supply Chain Management, investment in recycling, green purchasing, green logistics and green manufacturing which has strong evidence, both academic and economic benefits, to create significant economic value for the business.

2. The auto parts industries in Thailand should expedite the creation of knowledge, experience, tools to achieve efficiency and effectiveness in the operation of the environment, and to accept the critical principles of environmental logistics to the process seriously.

3. The auto parts industries in Thailand should set up industrial strategies and positions for internal management for the environment and collaborating with external vendors, production factors, and customers' needs for environmentally friendly products much more than in the past. To create the ability and competitive advantage for the business and the Thai auto parts industries.

4. The government and relevant domestic organizations support policy and implementation of environmental logistics management by using incentive measures instead of enforcing environmental laws, such as promoting green logistics knowledge and applicable domestic and international regulations. Providing support for low-interest loans and establishing tax cuts for incentives.

\section{Acknowledgment}

This research project was funded by The Thailand Research Fund (TRF), under the supervision of the Prime Minister's Office of Thailand, project code: RDG5650026, project name: Study of Green Logistics Managing Potential and the Preparedness of Auto Parts Industries in Thailand.

\section{References}

[1]. Green, K., Morton, B., \& New, S. (1998). Green purchasing and supply policies: do they improve companies' environmental performance?. Supply Chain Management: An International Journal, 3(2), 89-95.

[2]. Srivastava, S. K. (2007). Green supply-chain management: a state-of-the-art literature review. International journal of management reviews, 9(1), 53-80.

[3]. Dheeraj, N., \& Vishal, N. (2012). An overview of green supply chain management in India. Research Journal of Recent Sciences, 1(6), 77-82.

[4]. Kumar, A. (2015). Green Logistics for sustainable development: an analytical review. IOSRD International Journal of Business, 1(1), 7-13.

[5]. Carter, C. R., \& Rogers, D. S. (2008). A framework of sustainable supply chain management: Moving toward new theory. International Journal of Physical Distribution and Logistics Management, 38(5), 360387.

[6]. Zhu, Q., Sarkis, J., \& Lai, K. H. (2008). Green supply chain management implications for "closing the loop". Transportation Research Part E: Logistics and Transportation Review, 44(1), 1-18.

[7]. Kim, Y., Tanaka, K., \& Matsuoka, S. (2020). Environmental and economic effectiveness of the Kyoto Protocol. Plos one, 15(7), e0236299.

[8]. Wiedmann, H., \& Teichmann, J. (2008). „Next Level Purchasing ": Erfolgsfaktor eines aktiven Kostenmanagements. In Best Practice in Einkauf und Logistik (pp. 56-65). Gabler.

[9]. Bogaschewsky, R., \& Müller, H. (2008). Stand und Weiterentwicklung des E-Procurement in Deutschland. In Best Practice in Einkauf und Logistik (pp. 237-254). Gabler.

[10]. Goll, L., \& Haupt, S. (2008). Coporate Governance, Risk-and Compliance Management in der Beschaffung. In Best Practice in Einkauf und Logistik (pp. 149-168). Gabler. 
[11]. Hamprecht, J. (2005). Sustainable Purchasing Strategy in the Food Industry. University of St. Gallen (Doctoral dissertation, Ph. D. thesis).

[12]. Klumpp, M., Bioly, S., Saur, A., \& Zelewski, S. (2010). Green Supply Chain Event Management. In 8th Industrial Simulation Conference (pp. 195200).

[13]. Zhu, Q., Sarkis, J., \& Geng, Y. (2005). Green supply chain management in China: pressures, practices and performance. International Journal of Operations \& Production Management, 25(5), 449-468.

[14]. Jain, V. K., \& Sharma, S. (2012). Green supply chain management practices in automobile industry: An empirical study. Journal of Supply Chain Management Systems, 1(3), 20.

[15]. Sarkis, J. (2003). A strategic decision framework for green supply chain management. Journal of cleaner production, 11(4), 397-409.

[16]. Zhu, Q., Sarkis, J., \& Lai, K. H. (2007). Green supply chain management: pressures, practices and performance within the Chinese automobile industry. Journal of cleaner production, 15(11-12), 1041-1052.

[17]. Lin, R. J., Chen, R. H., \& Nguyen, T. H. (2011). Green supply chain management performance in automobile manufacturing industry under uncertainty. Procedia-Social and Behavioral Sciences, 25, 233-245.
[18]. Vachon, S., \& Klassen, R. D. (2006). Green project partnership in the supply chain: the case of the package printing industry. Journal of Cleaner production, 14(6-7), 661-671.

[19]. Firouzabadi, A.K, Olfat, L. \&Khodaverdi. R. (2010). Green supply chain management:pressures, practicesand performance. Proceedingsof the 8th International Conference on Manufacturing Research ICMR, 2010.

[20]. Etzion, D. (2009, August). Signal Dynamics: An Industry Level Analysis of The Diffusion of Environmental Management Systems. In Academy of Management Proceedings (Vol. 2009, No. 1, pp. 1-6). Briarcliff Manor, NY 10510: Academy of Management.

[21]. Steven, M. (2004). Networks in reverse logistics. In Supply chain management and reverse logistics (pp. 163-180). Springer, Berlin, Heidelberg.

[22]. Cruz, J. M., \& Matsypura, D. (2009). Supply chain networks with corporate social responsibility through integrated environmental decision-making. International Journal of Production Research, 47(3), 621-648.

[23]. Carter, C. R., \& Rogers, D. S. (2008). A framework of sustainable supply chain management: Moving toward new theory. International Journal of Physical Distribution and Logistics Management, 38(5), 360387.

[24]. Murphy, P. R., \& Poist, R. F. (2000). Green logistics strategies: an analysis of usage patterns. Transportation journal, 5-16.

[25]. Revell, A. (2007). The ecological modernisation of SMEs in the UK's construction industry. Geoforum, 38(1), 114-126. 